\title{
Wildlife Effects from Grasshopper Insecticides Sprayed on Short-Grass Range ${ }^{1}$
}

\author{
LOWELL C. MCEWEN, C. EDWARD KNITTLE, \\ AND MERLE L. RICHMOND \\ Research Biologists, Bureau of Sport Fisheries and Wildlife, \\ Denver, Colorado.
}

\section{Highlight}

Insecticides were sprayed experimentally at several sites on short-grass plains vegetation by the Agricultural Research Service (ARS), United States Department of Agriculture (USDA), to determine effectiveness for grasshopper (Acrididae) control. Effects of the applications on resident wildlife were studied by the Denver Wildlife Research Center. Observations were also made on the effects of an operational range caterpillar (Hemileuca oliviae) control program with toxaphene. Direct effects on birds varied widely with the chemicals applied, spray rates, and conditions. Applications (in ounces of active ingredient per acre) that killed birds and resulted in significant population decreases were: Fenitrothion (9.6 oz), BAY 77488 (4.6 and 9.3 oz), diazinon (5.0 to $8.0 \mathrm{oz}$ ), and toxaphene (16 oz). Applications that resulted in significant population decreases under some conditions, but without any observed bird mortality, were: Fenitrothion (6.3 oz), Baygon (3.0-4.0 oz), and Guthion (4.0 oz). Applications without observed direct effects on wildlife were: BAY 77488 (2.5 oz), carbaryl $(6.4 \mathrm{oz})$, malathion $(6.8 \mathrm{oz})$, and Mobam $(3.0 \mathrm{oz})$. Registration and use of pesticides for range grasshopper control should be limited to those that degrade rapidly in the environment, have the least direct impact on wildlife, and have been thoroughly field-tested.

For over 50 years range grasshopper outbreaks were fought with bran bait containing arsenic (Parker, 1952). About 1943, sodium fluosilicate replaced arsenic in many bait programs (Brown, 1951). By 1950, chlordane, toxaphene, and aldrin came into use in baits and as sprays and dusts (Parker, 1952). Other chlorinated hydrocarbons, such as dieldrin and heptachlor, soon followed.

In 1965 the U. S. Department of Agriculture (USDA) and some of the Canadian provinces discontinued their recommendation and use of chlorinated hydrocarbons for range grasshopper control. The basis for this decision was (1) the occurrence of insecticide residues in meat and milk, (2) persistence of these insecticides in the environment, and (3) adverse effects on fish and wildlife. Nevertheless,

\footnotetext{
${ }^{1}$ Appreciation for cooperation and assistance with the field work is extended to Fred Skoog, Frank Cowan, and C. C. Blickenstaff, ARS, USDA, Bozeman, Montana; field workers of the Plant Protection Division, ARS, USDA; and Douglas Hicks, Denver Wildlife Research Center, Bureau of Sport Fisheries and Wildlife.
}

some privately financed rangeland spraying with chlorinated hydrocarbons has continued up to the present time and there has been governmental use of toxaphene for range caterpillars until recently.

Replacement insecticides recommended by the USDA for grasshoppers were malathion at $9.7 \mathrm{oz}$ (8.0 fl. oz) per acre in an ultra low volume (ULV) application and carbaryl at 8.0 to $16 \mathrm{oz}$ per acre in a water formulation (Agricultural Research Service, 1969). Cooperative studies by the Agricultural Research Service and the Denver Wildlife Research Center had shown both these treatments to be effective against grasshoppers and of little direct hazard to upland wildlife at those application rates. Both chemicals are highly toxic and disruptive in aquatic habitats, however, and should not be sprayed on streams, lakes, or other wetlands. Since 1965, all of the USDA's largescale grasshopper control programs have used ULV malathion applicalions. $^{2}$ Carbaryl has not been sprayed on a large scale because of

\footnotetext{
${ }^{2}$ W. Watson, ARS, Denver, Colorado, personal communication.
}

formulation and handling problems. $^{3}$ This paper reports the results of continuing research to find other grasshopper pesticides of low hazard to range wildlife.

\section{Study Areas and Methods}

Insecticides studied in the field tests were:

BAY $77488^{4}$ - phenylglyoxylonitrile oxime $O$,O-diethyl phosphorothioate Baygon $^{4}$ - o-isopropoxyphenyl methylcarbamate

carbaryl - 1-napthyl $N$-methylcarbamate

diazinon - O,O-diethyl $O$ - (2-isopropyl4-methyl-6-pyrimidinyl) phosphorothioate

fenitrothion - $O, O$-dimethyl $O$-(4-nitro$m$-tolyl) phosphorothioate

Guthion $^{4}$ - $O, O$-dimethyl S-[4-oxo-1,2, 3-benzotriazin-3(4H)-ylmethyl] phosphorodithioate

malathion - O,O-dimethyl S-(1,2-dicarbethoxyethyl) dithiophosphate

Mobam ${ }^{5}$ - benzo [b]thien-4-yl methylcarbamate

toxaphene - a mixture of chlorinated camphenes $(67-69 \%$ combined chlorines)

All insecticide applications were made with aircraft operated by or supervised by the ARS.

Study areas were located in Montana, New Mexico, and Wyoming (Fig. 1). Each area consisted of a group of 40-, 80-, or 160-acre plots sprayed experimentally by the Agricultural Research Service (ARS) Grasshopper Investigations staff. One exception was an area near Springer, New Mexico, where a block of 177,000 acres of blue grama (Bouteloua gracilis) grassland was sprayed by the Plant Protection Division of the ARS in an operational range caterpillar control program.

All of the study areas were characterized by flat to rolling topography and short-grass plains vegctation. In addition to blue grama,

\footnotetext{
${ }^{3}$ F. Skoog, ARS, Bozeman, Montana, personal communication.

4 Trade names of Chemagro Chemical Corp. Reference to trade names does not imply endorsement of commercial products by the Federal Government. ${ }^{5}$ Trade name of Mobil Chemical Company.
} 


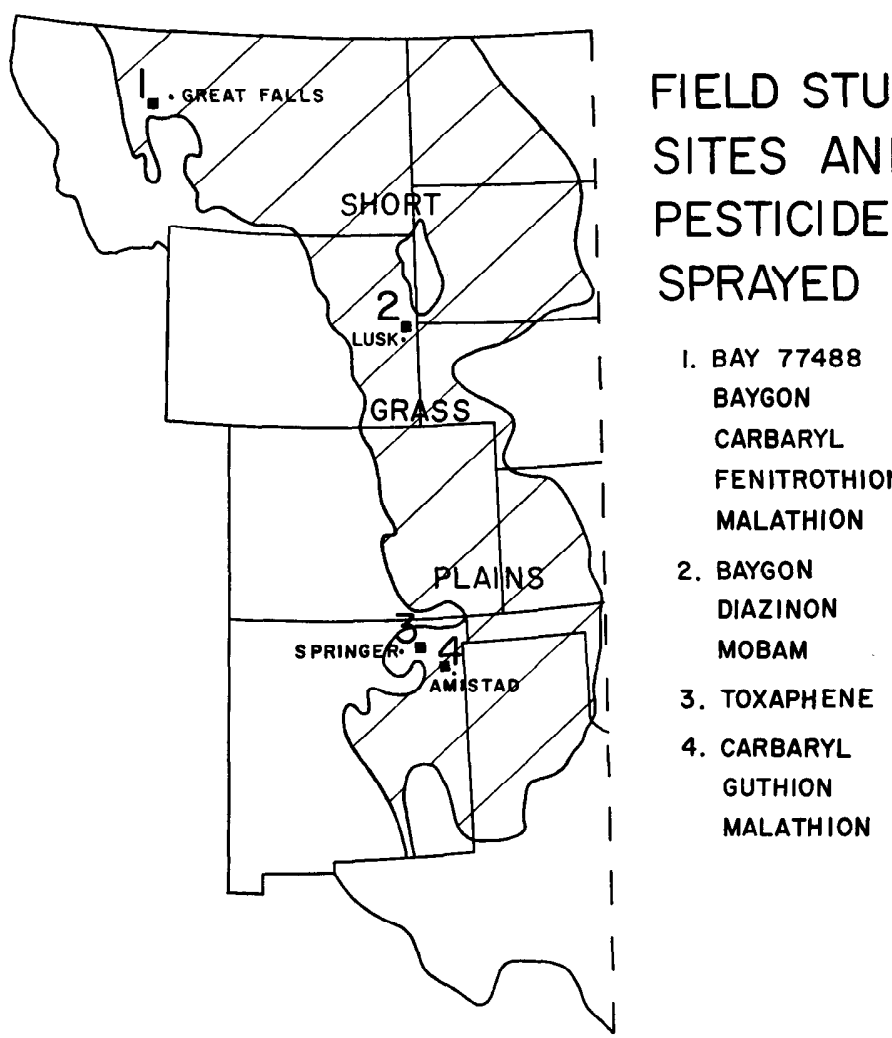

FIG. 1. Locations of study areas and kinds of pesticides sprayed.

other common plant species included needleandthread (Stipa comata), buffalograss (Buchloe dactyloides), upland sedges (Carex spp.), Junegrass (Koelaria crislata), western wheatgrass (Agropyron smithii), cheatgrasses (Bromus spp.), snakeweed (Gutierrezia sarothrae), fringed sagebrush (Artemisia frig$i d a$ ), and pricklypear (Opuntia spp.). Very few larger shrubs or trees were present other than occasional soapweed (Yucca glauca), chokecherry (Prunus virginiana), and skunkbush (Rhus trilobata), and a few cottonwoods (Populus spp.) near ranch buildings and windmills. Average annual precipitation at the four study sites varied from 14 to 17 inches. Elevation ranged from 3,400 to 6,600 feet.

Pre- and post-spray bird censuses were conducted on the sprayed plots and on similar plots that were not sprayed. Each census line was a straightline transect through the center of each plot. Transects on the 40 -acre plots were $1 / 4$-mile long and on the 80 - and 160 -acre plots were $1 / 2$-mile in length. On the range caterpillar control area, 1/2mile long transects were located at several sites within the treated area and on untreated range outside the area. Bird census transects were run between sunrise and 10:30 AM MDT to coincide with bird activity patterns. Censuses were not run in rain or snow or when wind velocity exceeded 12-15 mph. Half-mile transects were run in about 12 minutes and $1 / 4$-mile transects in 6-7 minutes. All birds seen within 150 feet of either side of the line of travel were identified and counted. Transient flocks of 5 or more birds were recorded but not included in the statistical analysis. Bird census results were analyzed by the " $t$ " test with an unequal number of observations (Snedecor, 1956).

Small mammals were censused with Sherman live-traps on a few of the treated and untreated plots. Captured animals were individually marked with a toe-clipping system and released for recapture studies. Trap lines consisted of 50 traps at 25 stations in a line, 50 feet between stations. Traps were usually set 3 nights in the pre-spray period and 3 nights in the post-spray period. Observations on larger mammals, such as rabbits, badgers, coyotes, antelope, and deer, were too limited for statistical tests. Usually only a few individuals were seen and they often ranged over several plots.

Searches for dead animals were conducted along some of the census transects and in likely places such as around stock ponds and windmills. The most successful carcass searches were made with the help of a dog, but in most studies no dogs were available.

In some cases, vegetation, insects, and vertebrates were collected from the plots for insecticide residue analysis by chemists at the Denver Wildlife Research Center. Guthion and diazinon samples were analyzed by gas chromatography with a flame photometric detector, carbaryl samples by thin-layer chromatography with some confirmatory samples by gas chromatography, and toxaphene samples by gas chromatography. Vertebrates were analyzed as wholebody samples, less integument, extremities, and gastrointestinal tract; insects and plants were analyzed as pools. Residues for vertebrates and insects are based on fresh weight; those for plants on air-dried weight.

Bird species present on all study areas, in order of abundance, were the horned lark (Eremophila alpestris), western meadowlark (Sturnella neglecta), lark bunting (Calamospiza melanocorys), mourning dove (Zenaidura macroura), common nighthawk (Chordeiles minor), killdeer (Charadrius vociferus), and sparrow hawk (Falco sparverius). Of the total of 59 species observed, the next most common were the chestnut-collared longspur (Calcarius ornatus), western kingbird (Tyrannus verticalis), brown-headed cowbird (Molothrus ater), long-billed curlew (Numenius americanus), upland plover (Bartramia longicauda), Franklin's gull (Larus pipixcan), vesper sparrow (Pooecetes gramineus), and Cassin's sparrow (Aimophila cassinii). Technical names follow the A.O.U. (1957). 
Table 1. Bird census (number/1/4-mile transect) results on BAY 77488, Baygon, and fentrothion test plots, Cascade County, Montana, 1969.

\begin{tabular}{|c|c|c|c|c|c|}
\hline \multirow[b]{2}{*}{ Insccticide } & \multirow{2}{*}{$\begin{array}{c}\text { Spray rate } \\
\text { (oz/acre) }\end{array}$} & \multirow{2}{*}{$\begin{array}{l}\text { No. of } \\
\text { counts }\end{array}$} & \multirow{2}{*}{$\begin{array}{l}\text { No. of days } \\
\text { post-spray }\end{array}$} & \multicolumn{2}{|c|}{ Avg. number of birds } \\
\hline & & & & Pre-spray & Post-spray \\
\hline BAY 77488 & 2.5 & 49 & $1-9$ & 23.1 & 19.3 \\
\hline BAY 77488 & 4.6 & 61 & $1-9$ & 14.8 & $10.1^{1}$ \\
\hline BAY 77488 & 9.3 & 39 & $1-9$ & 15.8 & $6.4^{1}$ \\
\hline Unsprayed & - & 70 & - & 18.6 & 17.8 \\
\hline Baygon & 2.0 & 31 & $1-7$ & 16.4 & 16.9 \\
\hline Baygon & 3.0 & 37 & $1-7$ & 18.5 & $10.5^{2}$ \\
\hline Baygon & 4.0 & 26 & $1-7$ & 19.9 & $12.7^{2}$ \\
\hline Unsprayed & - & 70 & - & 18.6 & 17.8 \\
\hline Fenitrothion & 6.3 & 26 & $1-5$ & 9.3 & $4.5^{2}$ \\
\hline Fenitrothion & 9.6 & 24 & $1-5$ & 9.1 & $3.3^{1}$ \\
\hline Unsprayed & - & 14 & - & 8.3 & 7.3 \\
\hline
\end{tabular}

${ }^{1}$ Differs from pre-spray, $\alpha=0.01$.

2 Differs from pre-spray, $\alpha=0.05$.

Mammals observed on all study areas were pronghorn antelope (Antilocapra americana) and deer mice (Peromyscus sp.). Mule deer (Dama (Odocoileus) hemionus), desert cottontails (Sylvilagus audubonii), coyotes (Canis latrans), striped skunks (Mephitis mephitis), jackrabbits (Lepus californicus and L. townsendii), badgers (Taxidea taxus), grasshopper mice (Onychomys leucogaster), and thirteenlined ground squirrels (Spermophilus tridecemlineatus) were the next most common of 24 species recorded. Technical names are after Hall and Kelson (1959).

Most of the 12 species of reptiles and amphibians were recorded on the New Mexico study plots. The great plains toad (Bufo cognatus), western box turtle (Terrapene ornata), prairie rattlesnake (Crotalus viridis), and gopher (bull) snake (Pituophis melanoleucus) were also common to one or both of the northern study areas. Technical names follow Stebbins (1954).

\section{Results}

\section{$B A Y 77488$}

The chemical was sprayed by ULV application at $2.5,4.6$, and $9.3 \mathrm{oz} /$ acre on twelve 40-acre plots in Cascade County, Montana. Chestnut-collared longspurs, horned larks, vesper sparrows and western meadowlarks were the most com- mon nesting birds on the plots. The $2.5 \mathrm{oz} /$ acre rate did not observably affect birds. The two higher rates of application caused some direct mortality and a significant decline in total birds (Table 1) and in all four of the most common species. The greatest decline occurred in the longspurs on the 9.3 oz plots. The overall decrease in birds averaged $32 \%$ on the $4.6 \mathrm{oz}$ plots and $59 \%$ on the $9.3 \mathrm{oz}$ plots.

Small mammals were livetrapped, marked, and released on one plot sprayed with $4.6 \mathrm{oz} /$ acre. Eight deer mice and one sagebrush vole (Lagurus curtatus) were captured in the pre-spray period. All were recaptured, alive and in apparent good condition one or more times in 5 days of post-spray trapping along with additional deer sonii).

BAY 77488 is not presently registered for use on rangeland. If registration is sought, further field study will be needed to confirm that the $2.5 \mathrm{oz} /$ acre rate is of little hazard to wildlife.

\section{Baygon}

Baygon was studied at two locations, Niobrara County, Wyoming, and Cascade County, Montana. In the first tests in Wyoming, no significant changes in numbers of birds (mainly horned larks) were mice and a Richardson's ground squirrel (Spermophilus richard- found. However, some of the Baygon crystallized, the grasshopper kill was poor, and wildlife exposure was not representative.

Further tests were conducted in Montana with an improved formulation at spray rates of 2.0, 3.0, and $4.0 \mathrm{oz} /$ acre on ten 40 -acre plots. Common birds were the same species as on the BAY 77488 plots. Total birds and two of the four major species (chestnut-collared longspurs and western meadowlarks) decreased significantly on plots sprayed with 3.0 and $4.0 \mathrm{oz}$ Baygon/acre but not on those sprayed with $2.0 \mathrm{oz} /$ acre (Table 1 ). The acute toxicity of Baygon (Tucker and Crabtree, 1970) to passerine and gallinaceous birds indicates a high potential for direct poisoning. Wildlife casualties observed on the Baygon plots were three dead nestling longspurs and one adult. Four active chestnutcollared longspur nests with eggs or nestlings were kept under observation. All were abandoned or otherwise unsuccessful after the Baygon was sprayed.

Five deer mice were live-trapped and marked pre-spray on the $3.0 \mathrm{oz}$ Baygon plot. All were recaptured alive and normal in appearance two or three more times each in 5 days of post-spray trapping. Results of the bird observations indicate that more Baygon field tests are needed before it can be recommended for grasshopper control.

\section{Carbaryl and malathion}

Eight 160-acre test plots in the short-grass plains of Union County, New Mexico, were sprayed with 6.4 oz/acre of carbaryl (Sevin ${ }^{\circledR}$-4-oil formulation) or $6.8 \mathrm{oz} /$ acre of malathion. The major species present were horned larks, western meadowlarks, Cassin's sparrows, mourning doves, and white-necked ravens (Corvus cryptoleucus). No effects on birds were detected (Table 2). A complicating factor in this study was the effect of rainstorms totalling 1.4 to 1.9 inches within 40 hours after the plots were sprayed. Grasshopper kills were poorer on 
these plots than on nearby carbaryland malathion-sprayed plots which did not receive any rain after treatment. The latter plots were not included in the wildlife observations, however.

In the post-spray period, smallmammal trapping on one of the carbaryl plots resulted in 25 recaptures of 18 apparently healthy deer mice, kangaroo rats (Dipodomys ordii), hispid pocket mice (Perognathus hispidus), and grasshopper mice. Larger mammals seen ranging across the sprayed plots, and not visibly affected, included black-tailed jackrabbits and pronghorns. Western box turtles, and lesser earless lizards (Holbrookia maculata) were also frequently seen on the plots before and after spraying.

Two Cassin's sparrows and seven rodents of three species were collected after the carbaryl application and analyzed for residues. One of the sparrows contained $1.4 \mathrm{ppm}$, but carbaryl was not found in the other samples above the detection limits of 0.5 ppm.

We have studied carbaryl and malathion at several other sites in mixed vegetative types. Rates of application ranged up to $1 \mathrm{lb}$./acre for carbaryl and $9.7 \mathrm{oz} /$ acre for malathion. No wildlife mortality has been observed in any of these tests, but significant decreases in bird populations due to emigration have occurred under some conditions.

\section{Diazinon}

Technical diazinon was sprayed ULV at 5.0 to $8.0 \mathrm{oz} /$ acre on twentyfour 80 -acre test plots in Niobrara County, Wyoming. Actual deposits of the chemical were slightly lower than the intended rates. Pre-spray bird counts averaged 26.6 birds per half-mile transect (Table 2); horned larks, western meadowlarks, lark buntings, and chestnut-collared longspurs were the most abundant species. The diazinon applications had a strong impact on the resident birds. Average birds per transect dropped to 11.1 , a significant de-

Table 2. Bird census (number/1/2-mile transect) results on plots sprayed with carbaryl, malathion, Guthion, diazinon, Mobam or toxaphene.

\begin{tabular}{lccccc}
\hline \hline Insecticide & $\begin{array}{c}\text { Spray rate } \\
\text { (oz/acre) }\end{array}$ & $\begin{array}{c}\text { No. of } \\
\text { counts }\end{array}$ & $\begin{array}{c}\text { No. of days } \\
\text { post-spray }\end{array}$ & \multicolumn{2}{c}{ Avg. number of birds } \\
\hline Carbaryl $^{1}$ & 6.4 & 28 & $1-7$ & 11.8 & Pre-spray \\
Malathion $^{1}$ & 6.8 & 28 & $1-7$ & 11.1 & 13.1 \\
Guthion $^{1}$ & 4.0 & 40 & $3-8$ & 18.7 & $11.4^{2}$ \\
Unsprayed $^{1}$ & - & 28 & - & 11.5 & 12.8 \\
Diazinon $^{3}$ & $5.0-8.0$ & 36 & $6-8$ & 26.6 & $11.1^{2}$ \\
Mobam $^{3}$ & 3.0 & 34 & $3-7$ & 14.2 & 12.5 \\
Unsprayed $^{3}$ & - & 8 & - & - & 20.1 \\
Toxaphene $^{4}$ & 16.0 & 18 & $8-14$ & 33.6 & $15.0^{5}$ \\
Unsprayed $^{4}$ & - & 18 & - & 24.3 & 28.3 \\
\hline
\end{tabular}

\footnotetext{
1 Plots located in Union Co., New Mexico, 1968.

${ }^{2}$ Differs from pre-spray, $\alpha=0.01$.

${ }^{3}$ Plots located in Niobrara Co., Wyoming, 1966.

4 Plots located in Colfax Co., New Mexico, 1966.

${ }^{5}$ Differs from pre-spray, $\alpha=0.01$ and from unsprayed area, $a=0.05$.
}

crease $(\alpha=0.01)$, by 6 to 8 days post-spray. Eight dead birds, representing all four major species, were found on the sprayed plots. Most likely only a small fraction of the dead birds were found because of the low probability of locating carcasses (Rosene and Lay, 1963). A dead pronghorn was also found on a sprayed plot. However, this animal had becn seen limping with a shoulder injury of unknown origin prior to the spray application, and death may have been related to the injury and only coincidental with the diazinon exposure.

One carcass of each of the four bird species found dead was analyzed for diazinon content; whole body residues ranged from 0.06 to $0.57 \mathrm{ppm}$. Three deer mice captured with snap traps contained $0.10,0.11$, and $0.17 \mathrm{ppm}$ diazinon. Muscle tissue from the dead pronghorn had 0.01 ppm.

Because of the severe effects on birds, diazinon should not be sprayed for range grasshopper control.

\section{Fenitrothion}

This chemical was sprayed ULV at two rates, 6.3 and $9.6 \mathrm{oz} /$ acre on eight 40-acre plots in Cascade County, Montana. Chestnut-collared longspurs were the most abundant resident birds, but horned larks, western meadowlarks, and vesper sparrows were also common. The average number of all four species of birds declined significantly within 5 days on all fenitrothion-sprayed plots. Numbers of birds on similar plots left unsprayed showed no significant changes during the same period of time (Table 1). Sick and dead birds were found on plots sprayed with $9.6 \mathrm{oz} /$ acre but not on those sprayed at $6.3 \mathrm{oz}$.

Laboratory tests with fenitrothion have shown moderate to high acute toxicity to birds and unusually severe cumulative effects with repeated exposures (Tucker and Crabtree, 1970). Future USDA plans are to test lower application rates $(1.0$ to $6.0 \mathrm{oz})$ for effectiveness against grasshoppers. Judging from available data, this chemical's effects on wildlife, even at lower application rates, should be thoroughly evaluated before operational use is allowed on rangeland.

\section{Guthion}

Eight 160-acre plots in Union County, New Mexico, were sprayed ULV with $4.0 \mathrm{oz} /$ acre Guthion. Horned larks, western meadowlarks, Cassin's sparrows, and white-necked ravens were common resident bird species. Pre-spray bird counts averaged 18.7 per $1 / 2$-mile transect. Postspray counts dropped to 11.4 /transect, a significant decrease (Table 2). 
All of the common bird species, except meadowlarks, showed the post-spray decline. No sick or dead birds were seen on the study plots, indicating that their disappearance was probably due to emigration.

Heavy rains of 1.4 to 1.9 inches fell on four of the Guthion plots within 40 hours after spraying. The decline in bird numbers was not nearly so great on these plots as it was on four plots that were sprayed after the rain. This suggested that the rainfall lessened the impact of the Guthion on resident birds on half the plots and reduced the overall post-spray decline.

There appeared to be no direct effect of the Guthion on small mammals. Only three grasshopper mice were marked in pre-spray trapping, and these were all recaptured, apparently in good condition, from 5 to 7 days post-spray. In addition, 15 new animals, including grasshopper mice, kangaroo rats, hispid pocket mice, and a spotted ground squirrel (Spermophilus spilosoma), were marked and recaptured a total of 12 times after the spray. Western box turtles and lesser earless lizards were common residents of the Guthion test plots and were not observably affected by the spray.

A few animal and vegetation samples were collected for Guthion residue analysis. One sample of blue grama, taken 10 hours after spraying, contained $89 \mathrm{ppm} \mathrm{Gu-}$ thion. Five later collections of grama and associated grasses and forbs taken from 34 to 120 hours after treatment contained 13 to 24 ppm. Dead and dying grasshoppers collected the day of spraying had 14 ppm Guthion. A Cassin's sparrow collected 1 day post-spray contained $2.2 \mathrm{ppm}$. Several other Cassin's sparrows, lark sparrows (Chondestes grammacus), and horned larks taken at 5 to 6 days post-spray contained 0.05 to $0.14 \mathrm{ppm}$. Two grasshopper mice taken 6 and 7 days post-spray had 0.48 and $0.30 \mathrm{ppm}$, but three collected 9 days post-spray did not contain any detectable Guthion.

Guthion at $4.0 \mathrm{oz} /$ acre appears more hazardous to wildlife than the insecticides in current use (malathion and carbaryl), but a lower rate of application or a different formulation could change this picture.

\section{Mobam}

This insecticide was sprayed at $3.0 \mathrm{oz} /$ acre on sixteen, 80 -acre test plots in Niobrara County, Wyoming. The most common birds on the plots were horned larks, western meadowlarks, and lark buntings. Pre-spray bird numbers were relatively low for the area, averaging 14.2 per $1 / 2$-mile transect, apparently because of the generally poor condition of the vegetation. Bird counts dropped after treatment, but the decrease was not significant at the 0.05 level (Table 2).

Mobam is only moderately toxic to birds in acute oral doses but has a high degree of cumulative action in chronic exposures (Tucker and Crabtree, 1970). It is not presently a candidate for use on rangelands. Further field studies would be necessary to evaluate wildlife hazards if this compound is to be registered.

\section{Toxaphene}

Toxaphene, a chlorinated hydrocarbon insecticide, was sprayed on about 177,000 acres of blue grama grassland in New Mexico for control of the range caterpillar. The toxaphene was applied at the rate of $1 \mathrm{lb}$. insecticide in $3 / 4$ pint fuel oil per acre. This study differed from the others in that the spray application was an actual control operation rather than a field experiment.

In the first week post-treatment, there was no change in bird numbers on the census lines, and little or no mortality was observed. During the second week post-spray, birds decreased significantly (Table 2) in comparison with untreated grama rangeland in the same area. Three horned larks, two meadowlarks, one killdeer, one cowbird, and one mourning dove were found dead on the sprayed area. Analysis of the carcasses indicated toxaphene residues ranging from less than $\mathbf{0 . 1}$ to $9.6 \mathrm{ppm}$. Toxaphene was not detected in four horned larks collected live before spraying, but ranged from 0.4 to $1.0 \mathrm{ppm}$ in four horned larks and one meadowlark collected live 2 to 3 weeks postspray.

Four samples of range caterpillars contained from 7.2 to $34.0 \mathrm{ppm}$ toxaphene, and four post-spray samples of blue grama had from 6.7 to 51.6 $\mathrm{ppm}$. Of three deer mice and one grasshopper mouse collected on the edge of the sprayed area, only one contained detectable toxaphene, and it was only a trace. Seven months after the toxaphene application, two grass samples and four horned larks were collected for analysis. ${ }^{6}$ The grass samples (mostly blue grama) contained 5.5 and 8.3 ppm toxaphene, while the horned larks had from 0.2 to $0.8 \mathrm{ppm}$.

Conclusions from this study were that toxaphene at $1 \mathrm{lb}$./acre had a severe impact on the grassland fauna and ecosystem. No attempt was made to estimate total direct kill of birds because of the large area and limited observations, but the number must have been high. Probably of greater importance was the ultimate effect of the toxaphene residues on the hundreds of thousands of resident and migratory birds on the area that were not directly killed by their exposure. The long-term effects of the toxaphene on wildlife populations and the grassland ecosystem are not known, but the pcrsistence of the material in the environment coupled with its toxicity to many forms of life give it a high potential for disruption of grassland ecological relationships.

\section{Discussion}

With the exception of the toxaphene investigation, field observations in each of these studies were completed within two to four weeks. Thus, only relatively short

${ }^{6}$ Personal communication from R. H. Hillen, Bureau of Sport Fisheries and Wildlife, Fort Collins, Colorado. 
term, or direct, effects of the pesticide applications could be detected.

The main criterion for determining effects was a comparison of the average number of resident birds seen during several successive preand post-spray counts on established census lines located on sprayed and unsprayed plots. This offered the only practical method of obtaining adequate quantitative data with the resources at hand. Most grassland birds are not randomly distributed during breeding but are selective of their habitat and are territorial at that time (Cody, 1968; Wiens, 1969). Because of their territorial behavior, daily counts of resident species on established transects will be quite consistent during breeding (Emlen, 1971). Thus, a significant change in bird numbers on sprayed plots, while similar unsprayed plots remain stable, indicates a response to the pesticide treatment. Accordingly, we feel that the census results of resident birds reported here are a valid first assessment of the relative hazards of the chemicals and rates of application tested.

Other criteria used in assessing effects of the pesticides included: (1) observations of sick birds showing signs of poisoning and (2) location of carcasses of dead birds. These criteria were generally of little value because of the inherent difficulties in observing sick birds and locating dead ones. Searching for small carcasses widely distributed over a large area is a notably unreliable method for determining pesticide effects (Rosene and Lay, 1963). Carcasses disappear rapidly because of scavengers (Davis, 1970) and decomposition.

When the number of resident birds declines in an area following spraying, there is some question as to whether this is detrimental to the population. It is highly unlikely that nesting birds can simply emigrate to unsprayed areas without losses. One of the tenets of wildlife management is that suitable habitat will already be fully occupied if "seed" populations of the species in question are present in the area. Secondly, even if unoccupied habitat were available for pesticide-displaced birds, there would be losses to predators and other stresses while they were seeking the new areas. Lastly, the harmful effects on nesting birds are self-evident. Eggs and nestlings are not mobile. $\Lambda$ bandonment of nests means either a complete loss of reproduction for the year, or at best, a second nesting attempt. Repeat nesting is generally much less successful than first attempts (Lack, 1954).

Grasshoppers are extremely important to wildlife. They are nutritious, being particularly high in protein, are widely distributed, and are easily available. Grasshoppers are important in the diet of more than 120 species of birds (Martin et al., 1951) as well as for many other kinds of wildlife. Young birds and other animals are often highly dependent on grasshoppers during their early growth, including many species that primarily eat seeds and other plant materials when full grown.

Despite the great utilization by wildlife, severe grasshopper outbreaks do occur. Whether presentday wildlife populations can effectively suppress heavy infestations is questionable. In the 1930's, flocks of 2,000 to 8,000 hawks, mostly Swainson's (Buteo swainsoni), rough-legged ( $B$. lagopus), and ferruginous ( $B$. regalis) hawks, were observed cleaning up large grasshopper concentrations on egg beds in Colorado and New Mexico (Wakeland, 1958). Similar cases of biological control of grasshoppers by other species of birds are reported by Wakeland and others. It is unfortunate that the most beneficial birds, such as many of the raptors and insectivorous species, have been those most severely affected by the world-wide cycling through the biosphere of DDT and related insecticides (Dustman and Stickel, 1969; Fyfe et al., 1969; Frost, 1969; Peakall, 1970; Porter and Wiemeyer, 1969; Rudd, 1969; and Stickel, 1968).
Heavy grasshopper infestations can virtually destroy the vegetative cover (Parker, 1952). Infestations of 30 or more grasshoppers per square yard can be reduced to less than one in a few days with an effective pesticide application (Parker, 1954), greatly decreasing the damage to the vegetation. While the need for grasshopper control is evident in many situations, a more basic problem is to determine the underlying causes of outbreaks. There is some evidence that high populations occur more often on range in poor condition (Nerney, 1958 ) and are related to drought (Gunn, 1960) and overgrazing (Smith, 1958). If this is true, prevention of grasshopper damage by better range management would be more desirable ecologically than by spraying pesticides.

The goal of range and wildlife managers should be (1) to reduce the potential for pest insect irruptions through improving range condition and (2) to utilize only rapidly degrading chemicals of low toxicity at the lowest possible rates when chemical control does become necessary. Total "ecological pest control" may never fully be realized in the more arid, droughty parts of the western range, but a general improvement in range condition should benefit the resident wildlife. Hopefully, this would also significantly reduce the need for spraying insecticides on rangelands.

\section{Literature Cited}

Agricultural Research Service. 1969. Grasshopper control. U. S. Dep. Agr. Farmers' Bull. No. 2193. 11 p.

American Ornithologists' Union. 1957. Check-list of North American birds. Fifth Ed. Lord Baltimore Press, Baltimore. $691 \mathrm{p}$.

Brown, A. W. A. 1951. Insect control by chemicals. John Wiley \& Sons Inc., N. Y. 817 p, illus.

Cody, M. L. 1968. On the methods of resource division in grassland bird communities. The Amer. Nat. 102 (924):107-147.

DAvis, D. E. 1970. Evaluation of technics for measuring mortality. J. Wildl. Diseases 6:365-375.

Dustman, E. H., and L. F. Stickel. 
1969. The occurrence and significance of pesticide residues in wild animals. Ann. N. Y. Acad. Sci. 160: 162-172.

Emlen, J. T. 1971. Population densities of birds derived from transcet counts. Auk 88:323-342.

Frost, J. 1969. Earth, air, water. Environment 11(6): 14-33.

Fyfe, R. W., J. Campbell, B. Hayson, AND K. Hodson. 1969. Regional population declines and organochlorine insecticides in Canadian prairie falcons. Canad. Field-Naturalist 83:191-200.

GunN, D. L. 1960. The biological background of locust control. Annu. Rev. Entomol. 5:279-300.

Hall, E. R., and K. R. Kelson. 1959. The mammals of North America. (2v.) Ronald Press Co., N. Y., 1,083 p. illus.

LACK, D. 1954. The natural regulation of animal numbers. Oxford Univ. Press, London. 343 p. illus.

Martin, A. C., H. S. Zim, ANd A. L. Nelson. 1951. American wildlife and plants. McGraw-Hill Book Co., New York. 500 p. illus.
Nerney, N. J. 1958. Grasshopper infestations in relation to range condition. J. Range Manage. 11:247.

PARKek, J. R. 1952. Grasshoppers. p. 595-605. In: Yearbook of Agriculture, 1952. Gov. Printing Off., Washington, D. C. 780 p. illus.

PARKER, J. R. 1954. Grasshoppers. A new look at an ancient enemy. U. S. Dep. Agr. Farmers' Bull. No. 2064. 40 p. illus.

Peakall, D. B. 1970. Pesticides and the reproduction of birds. Sci. American 222(4):72-78.

Porter, R. D., AND S. N. Wiemeyer. 1969. Dieldrin and DDT: Effects on sparrow hawk eggshells and reproduction. Science 165(3889): 199-200.

Rosene, W., JR., AND D. W. LAY. 1963. Disappearance and visibility of quail remains. J. WildI. Manage. 27:139142.

Rudd, R. L. 1969. Pesticide kinetics in ecosystems disturbed by man. In: Man and his environment, interaction and independence. (ed. by J. Y. Wang). San Jose St. Coll. 178 p.

SMITH, R. E. 1958. Natural history of the prairie dog in Kansas. Univ.
Kansas Museum Nat. Hist., Misc. Public. 16. 36 p.

SNEDECOR, G. W. 1956. Statistical methods. Fifth ed. Iowa St. Univ. Press, $\Lambda$ mes, Iowa. 534 p.

Sterbins, R. C. 1954. Amphibians and reptiles of western North America. McGraw-Hill Book Co., Inc. N Y. 529 p. illus.

Stickel, L. F. $1968 . \quad$ Organochlorine pesticides in the environment. USDI Fish and Wildlife Serv. Spec. Sci. Rpt.-Wildlife No. 119. 32 p.

T'ucker, R. K., and D. G. Crabtree. 1970. Handbook of toxicity of pesticides to wildlife. U. S. Dep. of the Interior, Resource Public. No. 84. $131 \mathrm{p}$.

Wakeland, C. 1958. The high plains grasshopper. U. S. Dep. Agr. Tcch. Bull. No. 1167. U. S. Govt. Print. Off., Wash., D. C. 168 p. illus.

Wrens, J. A. 1969. An approach to the study of ecological relationships among grassland birds. Ornith. Monogr. No. 8, Amer. Ornith. Union, Allen Press, Lawrence, Kans. 93 p. illus. 